\title{
Preliminary Identification of Potential Halophilic Bacteria Isolated from 'Asam Sunti' - Indonesian Traditional Herbs, in Inhibiting the Growth of E.coli and Salmonella spp.
}

\author{
Fannisa Putri, Hanna Indah, Gemilang Lara Utama \\ Faculty of Agro-Industrial Technology, University of Padjadjaran, Jl. Raya Bandung Sumedang KM.21, Sumedang, 45363, Indonesia \\ E-mail: fnsptr22@gmail.com
}

\begin{abstract}
The research aimed to determine potential halophilic bacteria isolated from Asam Sunti in inhibiting the growth of $E$. coli and Salmonella spp.. Research done experimentally and data analyzed by descriptive-exploratory method. Asam Sunti collected from market in Nanggroe Aceh Darussalam were cultured in Nutrient Agar (NA) with addition of 5 and $10 \%$ (w/v) NaCl and the total bacteria population was counted. Two different colonies isolated then identified by macroscopic, microscopic and gram staining. Abilities in inhibit the growth of E.coli and Salmonella spp. determined by diffusion well method on NA. Results showed that the best isolate was isolate A1 (rod shaped, gram negative bacteria) that resulting in $1.6 \times 10^{5} \mathrm{cfu} / \mathrm{ml}$ in $5 \% \mathrm{NaCl}$ and $1.2 \times 10^{5} \mathrm{cfu} / \mathrm{ml}$ in $10 \%$ NaCl with no inhibition abilities towards E.coli and $11 \mathrm{~mm}$ of clear zone inhibition towards Salmonella spp..
\end{abstract}

Keywords - Halophilic Bacteria, Asam Sunti, Inhibition, E.coli, Salmonella spp.

\section{INTRODUCTION}

Asam sunti is indigenous herbs from Nanggroe Aceh Darussalam (NAD) - a province in Indonesia, which made from bilimbi (Averrhoa bilimbi L.). In fresh form, bilimbi also used as rust remover, cosmetics and traditional medicine [1,2]. Bilimbi has an acid flavor, unique aroma, and ability to give consistency of the food so that used as seasoning material.

Since long time ago, bilimbi were traditionally fermented into asam sunti and then utilized as seasoning material. Fermentation process of asam sunti using traditional equipment and easy methods which hereditary given by their anchestors. Asam sunti (Figure 1) is kind of fermented pickle products which processed with dry salting method, brown, soft, chewy, sour and slightly salty [3].

Fermentation method of asam sunti shown the role of bacteria as shown in other pickle products which salting processed [4]. Presence of bacteria on asam sunti were influenced by indigenous bacteria grown in bilimbi such as Enterococcus faecalis, Lactococcus lactis and Lactobacillus plantarum [5].

Beside the role of bacteria, salting process in the making of asam sunti will also increase the possibility of halophilic bacteria growth. When used as free cells, salinity usually limits the growth of bacteria strains [6,7]. However, the combination of salts and bacteria in Chinese traditional fermented vegetables production could improve pickle fermentation [8].

Various bacteria are well known has the ability to inhibit pathogenic bacteria such as Eschericia coli and Salmonella spp.. Lactic acid bacteria could produce bacteriocins to inhibit Salmonella spp. and E. coli [9]. Inhibition abilities towards food borne pathogenic bacteria also found in bacteria isolated from home-made fermented vegetables products [10].

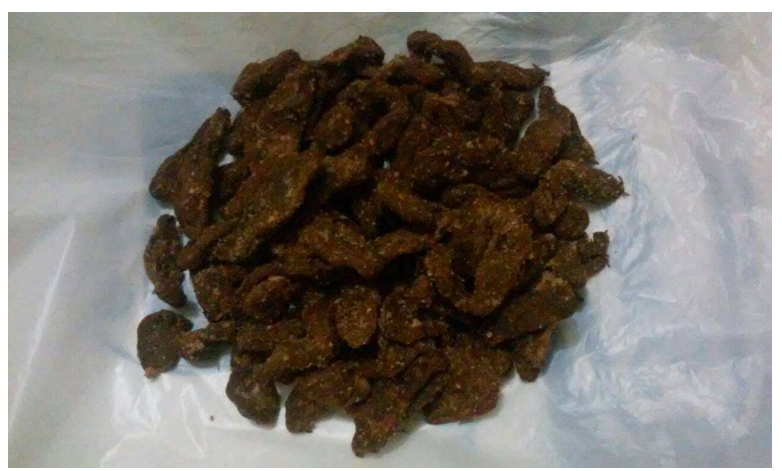

Fig. 1. Asam sunti-Indonesian indigenous herbs

The research aims to determined the inhibition abilities towards E.coli and Salmonella spp. from potential halophilic bacteria that isolated from asam sunti. Selected isolates 
could widely used in reducing contamination risk of E.coli and Salmonella spp. in salted products.

\section{MATERIALS AND METHODS}

Asam sunti bought from traditional market in NAD then diluted in $0.85 \% \mathrm{NaCl}$ solution. Samples solution for $0.1 \mathrm{ml}$ cultured in Nutrient Agar (NA) with addition of 5 and $10 \%$ (w/v) $\mathrm{NaCl}$, then incubated in $37^{\circ} \mathrm{C}$ for $24 \mathrm{~h}$ and the total bacteria population was counted [11]. Two different colonies with the highest total bacteria population isolated then identified by macroscopic, microscopic and gram staining. Abilities in inhibit the growth of E.coli and Salmonella spp. determined by well diffusion method on NA [12].

\section{RESULTS AND DISCUSSIONS}

Based on macroscopic and microscopical characteristic, Table 1 and 2 showed that five isolates identified from asam sunti. Four bacteria with cocci shape gram positives and one bacteria with rod shape gram negatives was found. Along with previous research, five cocci shape gram positives bacteria found on bilimbi that were raw materials of asam sunti [5].

TABLE I

MACROSCOPIC CHARACTERISTICS OF ISOLATES

\begin{tabular}{|c|c|c|}
\hline Isolate & Colour & Shape \\
\hline A1 & cream & Round \\
\hline A2 & cream & Assymetric \\
\hline A3 & cream & Jagged \\
\hline A4 & cream & Assymetric \\
\hline A5 & yellow & Round \\
\hline
\end{tabular}

TABLE III

MICROSCOPIC CHARACTERISTICS OF ISOLATES

\begin{tabular}{|c|c|c|}
\hline Isolate & Shape & Gram \\
\hline A1 & rod & - \\
\hline A2 & cocci & + \\
\hline A3 & cocci & + \\
\hline A4 & cocci & + \\
\hline A5 & cocci & + \\
\hline
\end{tabular}

Table 3 showed that only two isolates that could survive on media with the addition $\mathrm{NaCl}$ until $10 \%$ (w/v). Isolates A1 shown average bacteria population of $1.6 \times 10^{5} \mathrm{cfu} / \mathrm{ml}$ at $5 \% \mathrm{NaCl}$ added media and $1.2 \times 10^{5} \mathrm{cfu} / \mathrm{ml}$ population at $10 \% \mathrm{NaCl}$ added media. While, isolates $\mathrm{A} 4$ shown average bacteria population of $2.1 \times 10^{5} \mathrm{cfu} / \mathrm{ml}$ at $5 \% \mathrm{NaCl}$ added media, however the average bacteria population decreased until $1.0 \times 10^{5} \mathrm{cfu} / \mathrm{ml}$ at $10 \% \mathrm{NaCl}$ added media.

Halophilic bacteria were categorized based on their tolerance towards different salt concentrations [11]. Salt lower the water activity, it is shown by decreased of water activity from fresh bilimbi (0.936) into asam sunti after dry salting (0.730) and after one month fermentation (0.704) [3]. Bacteria with halophilic characteristics grow best in 1-5\% (w/v) salt, moderately halophilic bacteria tolerate 5-20\% salt [13]. Based on table 3 can be conclude that isolates A1 and A4 were moderately halophilic bacteria. The growth of slightly and moderately-halophlic bacteria do not require magnesium ion, grew better at the temperature of $28-37^{\circ} \mathrm{C}$ and $\mathrm{pH}$ of 7.0-8.0 on medium suplemented with $5-20 \% \mathrm{NaCl}$ $[14,11]$.

Table 3 also shown decreased of bacteria population influenced by the increase of $\mathrm{NaCl}$ concentration until $10 \%$. Between $0-6 \%$ of $\mathrm{NaCl}$, bacteria reduced their growth and between $6-10 \%$ of $\mathrm{NaCl}$, bacteria drastically reduced their growth [15]

TABLE IIIII

IDENTIFICATION OF ISOLATES HALOPHILIC CHARACTERISTICS

\begin{tabular}{|c|c|c|c|c|c|c|}
\hline \multirow{2}{*}{ Isolate } & \multicolumn{3}{|c|}{$\begin{array}{c}5 \% \text { NaCl }\left(\mathbf{1 0}^{3}\right) \\
\text { (x10 } \mathbf{c f u} / \mathbf{g})\end{array}$} & \multicolumn{3}{c|}{$\begin{array}{c}\text { 10\% NaCl } \\
(\mathbf{x 1 0} \text { cfu/g) }\end{array}$} \\
\cline { 2 - 7 } & R1 & R2 & R3 & R1 & R2 & R3 \\
\hline A1 & 158 & 174 & 155 & 114 & 128 & 119 \\
\hline A2 & $<30$ & $<30$ & $<30$ & $<30$ & $<30$ & $<30$ \\
\hline A3 & $<30$ & $<30$ & $<30$ & $<30$ & $<30$ & $<30$ \\
\hline A4 & 208 & 221 & 214 & 102 & 98 & 105 \\
\hline A5 & $<30$ & $<30$ & $<30$ & $<30$ & $<30$ & $<30$ \\
\hline *R = replication
\end{tabular}

Two isolates (A1 and A4) were tested to determine their inhibition abilities towards E.coli and Salmonella spp.. Table 4 showed that both isolates shown no inhibition abilities towards E.coli, however isolates A1 shown average $11 \mathrm{~mm}$ of clear zone diameter towards Salmonella spp. and $1 \mathrm{~mm}$ average clear zone diameter of inhibition towards Salmonella spp. from isolates A4 (Figure 2).

TABLE IVV

INHIBITION ABILITIES TOWARDS PATHOGENS

\begin{tabular}{|c|c|c|c|c|c|c|}
\hline Isolate & \multicolumn{3}{|c|}{$\begin{array}{c}\text { E. coli } \\
\text { (mm) }\end{array}$} & \multicolumn{3}{c|}{$\begin{array}{c}\text { Salmonella spp. } \\
\text { (mm) }\end{array}$} \\
\cline { 2 - 7 } & R1 & R2 & R3 & R1 & R2 & R3 \\
\hline A1 & - & - & - & 13 & 10 & 10 \\
\hline A4 & - & - & - & 1 & 0 & 2 \\
\hline
\end{tabular}
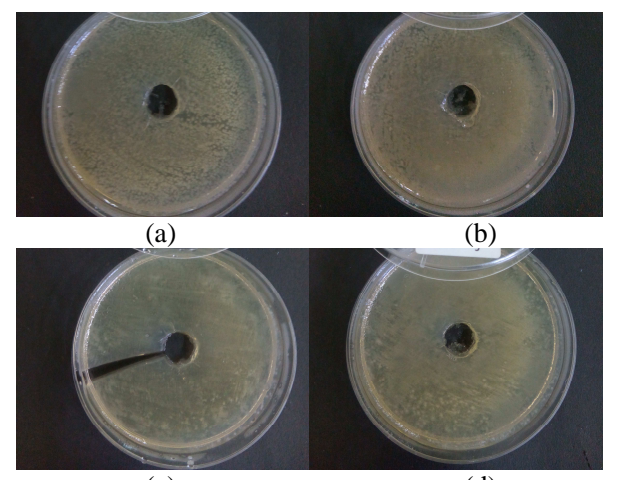

(c)

(d)

Fig. 2. Inhibition abilities (a) Isolates A1-E.coli, (b) Isolates A4-E.coli, (c) Isolates A1-Salmonella spp., (d) Isolates A4-Salmonella spp.

Inhibition abilities occured because of the accumulation of primary metabolites such as lactic acid, acetic acid, ethanol and carbon dioxide [10]. Some of lactic acid bacteria has abilities to produce antimicrobial compound such as formic acid, benzoic acid, hydrogen peroxide, diacetyl, acetoin and bacteriocin such as nicin [6]. Inhibition activities towards gram negatives bacteria such E.coli and Salmonella 
spp. could be caused by the production of organic acid and hydrogen proxide [17]. Large number of bacteria identified from variety plant sources mostly in the form of fermented and pickled products $[18,19]$.

\section{CONCLUSIONS}

Isolate A1 (rod shape, gram negative bacteria) which the best isolate shown $1.6 \times 10^{5} \mathrm{cfu} / \mathrm{ml}$ population in $5 \% \mathrm{NaCl}$ and $1.2 \times 10^{5} \mathrm{cfu} / \mathrm{ml}$ population in $10 \% \mathrm{NaCl}$ with no inhibition abilities towards E.coli and $11 \mathrm{~mm}$ of clear zone inhibition towards Salmonella spp..

\section{ACKNOWLEDGMENT}

We would like to thank Laboratory of Food Microbiology, Department of Food Technology, Faculty of Agro-Industrial Technology Universitas Padjadjaran for wide range of support on this research.

\section{REFERENCES}

[1] Wijayakusuma, H. Tanaman Berkhasiat Obat di Indonesia. Pustaka Kartini, Jakarta. 1993

[2] Tampubolon, O.T. Tumbuhan Obat. Bhratara, Jakarta. 1995.

[3] Muzaifa, M. "Physic characteristics change of bilimbi during fermentation of asam sunti (traditional fermented bilimbi of Aceh)" Jurnal Teknologi dan Industri Petanian Indonesia, vol. (5) no. 2. 2013.

[4] Molin, G. The Role of Lactobacillus plantarum in Foods and in Human Health, 2nd ed, Farnworth, E. R. Ed. Handbook of Fermented Functional Foods. CRC Press. 2003.

[5] Muzaifa, M. "Identification of indigenous lactic acid bacteria from bilimbing (Averrhoa bilimbi l.)" SAGU, vol. (13) no. 1. 2014.

[6] Ozer, B., Kirmaci, H. A., Senel, E., Atamer, M., and Hayaloglu, A. "Improving the viability of Bifidobacterium bifidum BB-12 and Lactobacillus acidophilus LA-5 in white-brined cheese by microencapsulation". International Dairy Journal, vol 19, p. 22-29. 2009.

[7] Karimi, R., Mortazavian, A. M., and Da Cruz, A. G. "Viability of probiotic microorganisms in cheese during production and storage: a review". Dairy Science and Technology, vol. 91, p. 283-308. 2011.
[8] Gao, S., Sun, Z., Du, X., Mao, C. And He, G. "Effect of inoculating lactic acid bacteria starter in los-walt pickle process of Zhacai". Advace Journal of Food Science and Technology, vol. 4, no. 6 , p. 442-444, 2012.

[9] Tatsadijeu, N.L., Njintang, Y.N., Sonfack K., Daoudou, B. Mbofung, C.M.F. "Characterization of lactic acid bacteria producing bacteriocins against chicken Salmonella enterica and Eschericia coli'. African J. of Microbiology Research, vol. 3 no. 5, p. 220-227, 2009

[10] Kazemipoor, M., Radzi, C., Begum, K., Yaze, I."Screening of antibacterial activity of lactic acid bacteria isolated from fermented vegetables against food borne pathogens". Archives des Sciences, vol. 65 , no. 6.2012.

[11] Roohi, A., Ahmed, I., Iqbal, M., Jamil, M. "Preliminary isolation and characterization of halotolerant and halophilic bacteria from salt mines of Karak, Pakistan”. Pak. J. Bot., vol. 44, p. 365-370. 2012.

[12] Roostita, L.B., Fleet, G.H., Wendry, S.P., Apon, Z.M., and Gemilang, L.U.'Determination of yeasts antimicrobial activity in milk and meat products". Advance Journal of Food Science and Technology, vol. 3 no. 6, p. 442-445, 2011.

[13] Lee, S.Y. "Microbial safety of pickled fruits and vegetables and hurdle technology". Journal of Food Safety, vol. 4, p. 21-32. 2004.

[14] Grant, W.D., M. Kamekura, T.J. McGenity and A.Ventosa. Order I Halobacteriales Grant and Larsen. in Eds. D.R. Boone, R.W Calstenholz and G.M.Garrity. Bergey's Manual of Systematic Bacteriology. $2^{\text {nd }}$ p. 294-334. Berlin: Springer-Verlag. 2001.

[15] Melgar-Lalanne, G., Rivera-Espinoza, Y., Farrera-Rebollo, R., Hernandez-Sanchez, H. "Survival under stress of halotolerant Lactobacilli with probiotic properties". Revista Mexicana de Ingenieria Quimica, vol. 13 no. 1, p.323-335. 2014.

[16] Yateem, A., Balba, M.T., Al-Surrayai, T., Al-Mutairi, B, Al-Daher, R. "Isolation of lactic acid bacteria with probiotic potential from camel milk". International Journal of Dairy Science, vol. 3, p. 194 199, 2008.

[17] Ito, A., Sato, Y., Kudo, S., Sato, S., Nakajima, H. Toba, T. "The screening of hydrogen peroxide-producing lactic acid bacteria and their application to inactivating psychrotropic food borne pathogens". Current Microbiology, vol 47, p. 231-236, 2003.

[18] Chiu, H. H., Tsai, C.C., Hsih, H.Y., Tsen, H.Y. "Screening from pickled vegetables the potential probiotic strains of lactic acid bacteria able to inhibit the Salmonella invasion in mice". Journal of Applied Microbiology, vol. 104 no. 2, p.605-612, 2008.

[19] Tamang, J.P., Tamang, B., Schillinger, U., Franz, C.M., Gores, M., Holzapfel, W.H. "Identification of predominant lactic acid bacteria isolated from traditionally fermented vegetable products of Eastern Himalayas". International Journal of Food Microbiology, vol. 105 no.3, p.347-356, 2005. 